\title{
P.G.R. de Villiers Dedication - A tribute
}

\begin{abstract}
Author:
Ernest van Eck ${ }^{1}$

Affiliation:

${ }^{1}$ Chairperson of the Executive Committee of the Editorial Board of HTS Teologiese Studies/Theological Studies

Correspondence to: Ernest van Eck

Email:

ernest.vaneck@up.ac.za

\section{Postal address:}

Private Bag X20, Hatfield

0028, Pretoria, South Africa

How to cite this article: Van Eck, E., 2015, 'P.G.R. de Villiers Dedication - A tribute', HTS Teologiese Studies/Theological Studies 71(1), Art. \#3171, 11 pages. http://dx.doi.org/10.4102/ hts.v71i1.3171

\section{Copyright: \\ (c) 2015. The Authors. Licensee: AOSIS OpenJournals. This work is licensed under the Creative Commons Attribution} License.
\end{abstract}

\section{P.G.R. de Villiers dedication: A tribute}

The Editorial Board of HTS Teologiese Studies/Theological Studies pays tribute to Prof Dr Pieter G.R. de Villiers, an internationally recognised scholar and esteemed colleague. Prof De Villiers has been the Executive Director of the Centre for Christian Spirituality and Ethics since 1990 and has been a Research Fellow and Professor Extraordinarius in Biblical Spirituality at the Department of Old and New Testament Studies at the Faculty of Theology, University of the Free State (since 2001). He is a member of 15 national and international academic societies (including invited membership of Studiorum Novi Testamenti Societas). He has edited 15 books, authored four monographs, published 120 peer-reviewed academic articles and chapters in books as well as numerous general articles and book reviews. During his academic career (since 1971), Prof De Villiers has been a member of several editorial boards and served in the executive of various academic societies. Currently, he is the chairperson of South African Association for Spirituality (SPIRASA), the executive Director of the Centre for the Study of Christian Spirituality and Ethics, the chair of the Mysticism Group of the New Testament Society of South Africa and editor of LitNetAkademies (Godsdienswetenskappe). Since January 2008, he has been the organiser of the NAVNUT project (Nederlandse, Afrikaanse, Vlaamse Nuwe-Testament Projek) on social justice and violence, power and peace. Similar international collaboration between Dutch and South African scholars was also a catalyst for the founding of the HTS in 1943.

\section{Contribution to research and research foci}

Prof De Villiers' impressive publication list bears testimony to his expertise in New Testament Studies. He has published on the Synoptic Gospels and Acts, apocalypticism, non-canonical writings (4 Ezra and the Similitudes of Enoch), hermeneutics (postmodernity and the relationship between history and faith), exegetical approaches and methods (narratology, sociological text analysis and linguistics), theological and related topics (the unity of the church, Judaism, Graeco-Roman society, miracles, superstition) as well as Pauline (1 Thessalonians, Philemon), Deutero-Pauline (2 Thessalonians), and Trito-Pauline literature (1 Timothy). His most extensive publications are on Revelations, socio-ethical themes and spirituality.

He has been doing research in the field of spirituality since 1997, often in collaboration with colleagues from the Netherlands, the United States and the United Kingdom, and has published 30 articles in this field. His research has contributed to establishing spirituality as a discipline of Biblical Studies in South Africa and to its international advancement. He is currently developing a program in Biblical Spirituality which reflects the African context and aims to publish handbooks and monographs on this topic.

Flowing from his research on spirituality, with its focus on the spiritual nature and impact of biblical texts, are his publications on themes such as peace, love and joy, mysticism and discernment in biblical texts. Prof De Villiers is specifically interested in identifying and interpreting texts with a spiritual dimension that are often overlooked in academic scholarship. His research investigates the spiritual nature of specific New-Testament texts and elucidates the relationship between theological themes and the faith experience of early Christian communities. Themes such as violence, power and peace are investigated in collaboration with international scholars. Prof De Villiers' publications on violence and peace are extensive, and he has established himself nationally as a leader in the field.

Prof De Villiers believes in engaged rather than ivory tower New-Testament scholarship. As early as 1989, he played a leading role in the empowerment of students from previously disadvantaged contexts and contributed to the democratisation and deracialisation of theological training at Rhodes University. His commitment to social justice can be seen in his research foci. Aspects such as peace, violence and power have socio-economic and socio-political implications. His work contributes to the building of a just and non-violent South Africa, striving for peace and joy for all. 
It is therefore befitting that Prof De Villiers has been invited to present the second A.S. Geyser Commemoration Lecture in 2016, hosted by the Department of New Testament Studies, Faculty of Theology, at the University of Pretoria.
With this edition of the HTS, the Editorial Board pays tribute to an esteemed scholar, colleague and friend who, for the past 44 years, has contributed significantly to the development of theology as an academic enterprise. 


\section{Appendix 1}

\section{Curriculum Vitae: Pieter G.R. de Villiers}

\section{Personal information}

- Born in Venterstad, South Africa, as eldest son in a family of five children.

- Married to Susan de Villiers, a university librarian/archivist, and has three daughters (Elizabeth, Elsje and Judith, as well as two grandchildren).

\section{University degrees}

- 1966: B.A. (cum laude) (University of Stellenbosch, South Africa) with Greek and Hebrew as majors, Philosophy, Psychology, Latin and Afrikaans as degree subjects.

- 1969 (March): B.A. Honours in Greek (cum laude) (University of Stellenbosch, South Africa).

- 1969 (November): B.Th. (cum laude) (University of Stellenbosch, South Africa), three-year degree in theological disciplines.

- 1973: Th.Drs. in New Testament Studies (Kampen Theological University, The Netherlands).

- 1974: Licentiate in Theology (cum laude) (University of Stellenbosch, South Africa).

- 1976: D.Th. in New Testament Studies (University of Stellenbosch, South Africa). (Doctoral theses in South Africa are not graded).

\section{Present and past member of scholarly societies \\ On invitation only}

- Studiorum Novi Testamenti Societas (SNTS)

\section{Others}

\section{Society of Biblical Literature.}

- American Academy for Religion.

- American Philological Association.

- Society for the Study of Christian Spirituality (presently a Board Member).

- European Association for Jewish Studies.

- European Association of Biblical Studies.

- The International Organization for Septuagint and Cognate Studies.

- New Testament Society of South Africa (former member of the executive).

- Old Testament Society of South Africa.

- South African Society for Patristic and Byzantine Studies.

- South African Society for Biblical and Religious Studies (former chairperson of the executive).

- South African Society for Jewish Studies.

- South African Society for Science of Literature.

- Association of Southern African Theological Institutions (former member of the executive).

- D.A.A.D. Alumni Association of South Africa (former chairperson of the Management Council).

- SPIRASA (Spirituality Association of South Africa) (member of the executive).

\section{Academic positions}

- Lecturer in the Department of Biblical Studies (Faculty of Arts) at the University of Stellenbosch, South Africa (1971-1978).

- Senior Lecturer in the Department of Biblical Studies (Faculty of Arts) at the University of Stellenbosch, South Africa (1978-1984).

- Professor in the Department of New Testament at the University of South Africa (1984-1988).
- Head of the C.B. Powell Bible Centre in the Faculty of Theology at the University of South Africa (1984-1988).

- Professor of New Testament in the Faculty of Divinity at Rhodes University (1989-2002).

- Head of the Department of Divinity, Rhodes University (1990-1992).

- Executive Director of the Centre for the Study of Christian Spirituality and Ethics (1990-).

- Professor Extraordinarius and Research Fellow in the Department of New Testament in the Faculty of Theology, University of the Free State (2001-).

\section{Merit awards and research grants}

- Merit awards for academic excellence from the University of Stellenbosch (B.A. studies).

- Elize Visser Scholarship at the University of Stellenbosch.

- H.B. Webb Stipendium for B.A. Honours studies in Greek (1968-1969).

- Merit award for the best student in the second-year theology class of the Faculty of Theology at the University of Stellenbosch (1969).

- Merit awards from the University of Stellenbosch (B.Th. studies).

- D.A.A.D. stipendium (German Academic Exchange Scholarship) for study in the Federal Republic of Germany at the Theological Faculty of the University of Göttingen (Georg-August Universität, 1973).

- Senior Research Grant from the Human Sciences Research Council of South Africa (HSRC) to do research at Duke University (Durham, North Carolina, USA) on apocalyptic literature (with Prof J.H. Charlesworth). Visiting Fellow at Duke University (1980).

- Human Sciences Research Council Travel Grant to attend the annual meeting of the Society of Biblical Literature in San Francisco (1981).

- Research grant from the University of Stellenbosch for a research project on apocalyptic literature (1982).

- Human Sciences Research Council Travel Grant to attend the annual meeting of the Society of Biblical Literature in New York (1982).

- Ad Hoc Research Grant from the Human Sciences Research Council of South Africa and the University of Stellenbosch to research the topic, Wisdom in 1 Enoch. A study on the speculative element in apocalyptic literature (1983).

- Human Sciences Research Council Travel Grant to attend the annual meeting of the Society of Biblical Literature and of the Studiorum Novi Testamenti Societas in Basel (1984).

- University of South Africa grant and Senior Research Grant from the Human Sciences Research Council to research the topic, The relationship between Christianity and Judaism in the Acts of the Apostles, at Yale University (New Haven, USA). Research Fellow at Yale University (Divinity School, 1986-1987).

- Rhodes University Research Grants for various projects and trave grants to attend international meetings (1988-2000).

- Grants from the Human Sciences Research Council (National Research Foundation), Stellenbosch University and Rhodes University to invite international scholars (mostly experts on Jewish early Christian literature) to South Africa, amongst them Proff Jim H. Charlesworth, Lars Harman, G.W.E. Nickelsburg, Richard Bauckham, A.J. Malherbe and Wayne A. Meeks (USA).

- Rhodes University Grant and Senior Research Grant from the Human Sciences Research Council (National Research Foundation) to do research on the topic, The household under threat in the Pastoral Epistles at Yale University in New Haven, USA. Research Fellow at Yale University (Divinity School, 1992-1993).

- Supervisor Grants to Senior Academics from the Human Sciences Research Council (NRF) for master's and doctoral students in 1997-1999.

- Research Funding from the University of the Free State to do research in The Netherlands and Germany (2002-2015).

- Research Grant from the D.A.A.D. (Wiedereinladung) to conduct research at the Ludwig Maximilians University in Munich, Germany in co-operation with Prof Jörg Frey (2004). 
- Research Grant from the D.A.A.D. (Wiedereinladung) to conduct research at the University of Regensburg, Germany in co-operation with Prof Tobias Nicklas (2009).

\section{Academic experience}

- Research Institutions and committees

- Member of the Advisory Panel for Theology, Religious Studies, Ancient and Near Eastern Studies of the National Research Foundation (NRF) for 1990-1991 and 1995-1998.

- Chairperson of the Advisory Panel for Theology, Religious Studies, Ancient and Near Eastern Studies of the National Research Foundation (NRF) from 1997-1998.

- Member of the University Research Committee of the Faculty of Theology at Stellenbosch University and of Senate at Rhodes University as well as the Library Committee of Senate of Rhodes University.

\section{- Teaching}

- Tutor in Greek at the University of Stellenbosch (1968-1969).

- Teaching undergraduate and postgraduate courses in Biblical Studies (mainly New Testament) at the University of Stellenbosch (1971-1984).

- Teaching New Testament at the University of South Africa (19841988).

- Teaching New Testament Studies from undergraduate to postgraduate level at Rhodes University (1989-2002).

- Teaching Spirituality in the honours as well as in the master's programs at Rhodes University.

- Teaching a master's degree (course work) in spirituality at the University of the Free State.

- Part-time teaching in the Department of Ancient Studies at the University of Stellenbosch.

- Visiting professor at the Christian University of St Petersburg, Russia (2004, 2006 and 2010).

- Visiting lecturer at various universities in Switzerland, the Netherlands, Belgium, Germany, the United Kingdom and Namibia.

\section{- Supervision of Research}

- Supervised master's and doctoral theses at the Universities of Stellenbosch, University of South Africa, Rhodes University and the University of the Free State.

- Leader of a master's degree course in spirituality at the University of the Free State.

\section{- External examining and evaluation}

- External evaluator and examiner of postgraduate theses at several South-African universities (University of the Witwatersrand, University of Pretoria, University of the Free State, Stellenbosch University, University of Potchefstroom, University of Kwa-Zulu Natal, University of South Africa, The Joint Board of Theological Institutions in Southern Africa and the University of Namibia).

- Refereeing

- Referee for the National Research Foundation (NRF) of the Human Sciences Research Council of South Africa for grants and overseas conferences, as well as articles for journals in the field of Old and New-Testament Studies, both locally and abroad.

\section{Executive positions in scholarly societies}

- Publications Secretary of the New Testament Society of South Africa (1981-1989).

- Co-chair of the Background group of the New Testament Society of South Africa.
- Co-chair of the Religious experience group of the New Testament Society of South Africa.

- Co-chair of the Mysticism Group of the New Testament Society of South Africa.

- Member of the executive of the Association of Southern African Theological Institutions (1992-1995).

- Member of the executive of the South African Society for Biblical and Religious Studies.

- Treasurer of the South African Society for Biblical and Religious Studies (1998).

- Chairperson of the South African Society for Biblical and Religious Studies from 1999 to 2004.

- Member of the Management Council of the German Academic Exchange Service (DAAD) Alumni Society of South Africa (1999-2005).

- Chairperson of the German Academic Exchange Service (DAAD) Alumni Society of South Africa (2000-2005).

- Member and chairperson of the South African Association for Spirituality (SPIRASA).

- Executive Director of the Centre for the Study of Christian Spirituality and Ethics (1990-).

- Organizer of NAVNUT (Nederlandse, Afrikaanse, Vlaamse NuweTestament Projek) since January 2008 (for South African, Dutch and Flemish scholars). Conceptualized, organized and co-organized two conferences held by the group (on violence and power) and coorganized the third conference on peace.

- Organizer of the Second Bi-Annual Meeting of the Society for the Study of Christian Spirituality (SSCS) in Johannesburg (May 2015).

\section{Editorial boards}

- Member and chair of the International Relations Committee (IRC) of the Society of the Study of Christian Spirituality (SSCS).

- Editor of Neotestamentica, the Journal of the New Testament Society of South Africa (1981-1989).

- Member of the Editorial Board of Theologia Evangelica (1986-1988).

- Member of the Editorial Board of Scriptura.

- Member (co-worker) of the Editorial Board of Nederduitse Gereformeerde Teologiese Tydskrif (2003-).

- Member of the Editorial Board of Acta Patristica et Byzantina.

- Member of the Editorial Board of Neotestamentica. The Journal of the New Testament Society of South Africa.

- $\quad$ Editor of LitNet Akademies (Godsdienswetenskappe).

- Member and Associate Editor of AOSIS Scholarly Publications, Domain Religion.

- Chair (since 2015) of the Editorial Board of Neotestamentica.

- Member of the Editorial Board of Spiritus, the journal of the Society for the Study of Christian Spirituality (SSCS).

\section{Linguistic training and competence}

- Ancient languages:

- Latin

- Greek

- Hebrew

- Aramaic

- Syriac

- Coptic

- Modern languages:

- German (Certificate in intermediate German; Goethe Institut, 1973)

- Dutch

- Afrikaans

- English

- French 


\section{Church involvement}

- Licensed as minister of religion in the Dutch Reformed Church of South Africa (1974).

- Ordained as minister of religion in the Dutch Reformed Church of South Africa (1993).

- Pastoral minister in the Uniting Reformed Church (Eersterust, Pretoria, 1985-1988).

- Served on a number of church boards, church commissions and synods of the Dutch Reformed Church of South Africa in Stellenbosch and Grahamstown.

\section{Other activities and interests}

- Member of several community societies and their executives (social, historical, educational and classical societies):

- member of the School Committee of Stellenbosch Primary School (1983-1984)

- member of the Governing Body of P.J. Olivier High School in Grahamstown (1994)

- member of the Executive of the Governing Body of P.J. Olivier High School (1996)

- chairperson of the Governing Body as well as of its Executive (1996).

- Warden of Helshoogte Residence at Stellenbosch University (19761980).

- Patron of the Undergraduate Society of Theological Students (Admissiebond) at Stellenbosch University.

- Squash

- Played league squash in Stellenbosch, Pretoria and Grahamstown

- Chairperson of the Rhodes University Squash Club in 1991.

- Representative of the Rhodes University Senate on the Sports Committee of the University.

- Passed the final examinations in piano (University of South Africa, 1966).

- Computer Science (Rhodes University, 2002).

- Running: occasional participation in marathons.

\section{Scholarly papers read at conferences}

- 1978 , 'The Messiah and messiahs in Jewish apocalyptic', paper read at the annual meeting of the New Testament Society of South Africa.

- 1981, 'Understanding the way of God: Form, function and meaning of the historical review in 4 Ezra 3:4-27', paper read at the annual meeting of the Society of Biblical literature in San Francisco.

- $\quad$ 1982, 'The Ezra-legend in 4 Ezra 13', paper read at the annual meeting of the Society of Biblical literature in New York.

- 1982, 'Configuration and plot in Matthew 19-22: Aspects of the narrative character of the Gospel of Matthew', paper read at the annual meeting of the New Testament Society of South Africa.

- 1982, 'The service of the believer', paper read at the Theological Faculty of the University of Stellenbosch.

- 1982 , 'The motive of chastisement in Hebrews 12', paper read at the Theological Faculty of the University of Stellenbosch.

- 1982 , 'Renaissance of sociological text analysis', paper read at the Theological Faculty of the University of South Africa, Pretoria.

- 1983, 'Religious teaching in Cape Schools', paper read at the Southern African Society for Biblical Studies in Pretoria.

- $\quad 1983$, 'Revealing the secrets: Wisdom and the world in the Similitudes in Enoch', paper read at the annual meeting of the New Testament Society of South Africa in Johannesburg.

- 1983, 'Solving the riddle: Towards a consensus in apocalyptic research?', paper read at the annual meeting of the Old Testament Society of South Africa.
- 1983, 'Relevance of general linguistics for the reading of classical texts', paper read at a public seminar organised by the Department of General Linguistics of the University of Stellenbosch (with J.C. Thom).

- 1984, 'The interpretation of a text in the light of its socio-cultural setting', paper read at the annual meeting of the New Testament Society of South Africa at Rustenburg.

- 1985 , 'Miracles in the time and world of the Bible', paper read at the University of South Africa.

- 1985 , 'Acts 15: The meeting in Jerusalem', paper read at the University of South Africa.

- 1985, 'The use of Scripture and modern society: Political interpretations of the Bible', inaugural lecture at the University of South Africa.

- 1988 , 'Symbols in the Apocalypse of John', paper read at the annual meeting of the New Testament Society of South Africa.

- 1989, 'New Testament scholarship in South Africa', paper read at the annual meeting of the New Testament Society of South Africa.

- 1990, 'Offering hope to a broken society: Contextualization in Titus', inaugural lecture at Rhodes University.

- 1990 , 'Luke and the language of the New Testament', paper read at the annual meeting of the New Testament Society of South Africa.

- 1992, 'The Church and development: Determining priorities', paper read at a conference on Church and Development, University of the Western Cape.

- 1993, 'The opponents in 1 Timothy', paper read at the Faculty of Theology, University of Geneva.

- 1993, 'The life of Jesus', workshop at the annual meeting of The Association of Southern African Theological Institutions in Johannesburg.

- 1993, 'The Bible and the Struggle (for power)', keynote address at the annual meeting of the Southern African Society for Biblical Studies.

- 1995, 'Is there a Bible in the Church?: On disempowering New Testament scholarship', paper read at the New Testament Society of South Africa in Pietermaritzburg.

- 1995, 'The uniqueness of Christ in a pluralistic society', paper read at the annual meeting of the Society for Biblical Studies, RAU, Johannesburg.

- 1995, 'Myths and genealogies in 1 Timothy', paper read at the Society of Biblical Literature in Budapest.

- 1995, 'Wisdom in the Book of Revelation and Daniel: A study in intertextuality', paper read at the annual meeting of the Old Testament Society of Southern Africa, UPE, Port Elizabeth.

- 1996, 'The second beast as false prophet in Revelation 13:11-18', paper read at the annual meeting of the Studiorum Novi Testamenti Societas in Strasbourg.

- 1996, 'The vice of conceit in 1 Timothy: A study in the ethics of the New Testament within its Graeco-Roman context', paper read at the annual meeting of the Society of Biblical Literature in New Orleans, USA.

- 1996, 'The Bible and politics', paper read at the annual meeting of the Southern African Society for Biblical Studies at the University of the Free State in Bloemfontein.

- 1997, 'Prophecies, oracles and signs in Graeco-Roman society', paper read at a conference of the South African Patristic and Byzantine Society in Pretoria.

- 1997, 'Biblical Studies and spirituality', paper read at the annual meeting of the Old Testament Society of South Africa at Vista University, Pretoria.

- 1998 , 'Chained for a thousand years: Satan in Revelation 20', paper read at the international conference of the Studiorum Novi Testamenti Societas in Copenhagen.

- 1998, 'Faith experienced: Hermeneutical perspectives on Biblical Studies and spirituality', paper read at the annual meeting of the New Testament Society of South Africa.

- 2000, 'The seven letters in Revelation 2-3', paper read at the annual meeting of the New Testament Society of South Africa. 
- 2001, 'New Historicism and the interpretation of Revelation', paper read at the international meeting of the Society of Biblical Literature in Rome.

- 2001 , 'The new policy on religion in schools', paper read at the annual meeting of the South African Society for Biblical and Religious Studies.

- 2002, 'The seven letters in Revelation 1-3: Coherence and structure', paper read at the annual meeting of the New Testament Society of South Africa.

- 2002, 'The historical Jesus', paper read at the Theological Faculty, University of Stellenbosch.

- 2002, 'Rome in the Book of Revelation', paper read at the annual meeting of the South African Society for Patristic and Byzantine Studies.

- 2003, 'Spirituality in and of the Book of Revelation: A case study on the changing nature and ethos of New Testament as a discipline', paper read at the annual meeting of the New Testament Society of South Africa (University of Natal, Pietermaritzburg), 25 April.

- 2003, 'Interpreting Revelation in the new millennium', paper read at the Faculty of Theology, University of Stellenbosch.

- 2003, 'Obscurity and ambiguity in pagan oracles and Revelation', paper read at an International Colloquium at McGill University, Montreal.

- 2003, 'The Bible and violence', F.C. Fensham Memorial Lecture, University of Stellenbosch, September.

- 2004, 'Apocalyptic literature', paper read at the Department of Old and New Testament Studies, February.

- $\quad 2004$, 'The composition and structure of Revelation 6-8', paper read at the annual meeting of the New Testament Society of South Africa, April.

- 2004, 'The resurrection in the New Testament', paper read at the Theological Faculty, Stellenbosch. 30 September.

- 2004, 'The seven angels in Revelation 14: An intertextual perspective', paper read at the Alexander von Humboldt-Kolleg, 12-14 August, University of Stellenbosch.

- 2004, 'Following the radical Jesus in the quest for a humane society: The contribution of Biblical spirituality to the new struggle against violence', opening paper read at the SAAP Conference for Ministers, Stellenberg, 14 September.

- 2004, 'The composition of Revelation', paper read at the doctoral seminar of the University of Munich.2005, 'Last, but not least?: The seven bowls in Revelation 16', paper read at the annual meeting of the New Testament Society of South Africa, Bloemfontein, University of the Free State, 13 April.

- 2005, 'The ethics of 1 Timothy', paper read at the University of Pretoria, 15-17 Augustus.

- 2005, 'Shaping the common future: Academic exchange and scientific cooperation between South Africa and Germany', presentation at the DAAD workshop, Johannesburg, 5 November.

- 2006, 'The locusts as symbol in the fifth trumpet in the light of Revelation as a prophecy', paper read at the annual meeting of the New Testament Society of South Africa, Pretoria, University of Pretoria, 19 April.

- 2006, 'Kanagaraj on mysticism in the Gospel of John', paper read at the annual meeting of the New Testament Society of South Africa, UNISA, Pretoria, 14 November.

- 2006, 'Joy in the Book of Revelation', paper read at the conference of the European Association of Biblical Studies, Hungary, 7 Augustus.

- 2007, 'Mysticism and the New Testament', paper read at the annual meeting of the New Testament Society of South Africa, Stellenbosch, 2-5 April.

- 2007, 'Mysticism in Revelation', paper read at an expert meeting at the Titus Brandsma Institute for Spirituality, Radboud University, Nijmegen, June.

- 2007, 'The septet of seven trumpets in Revelation', paper read at the Free University in Brussels, 11 June.
- 2007, 'The eschatology of 1 and 2 Thessalonians', paper read at an international conference on Eschatology in the New Testament, organized by the University of Pretoria, 19-23 August.

- 2007, 'The ethical implications of violent and vengeful language in Revelation', paper read at the Society of Biblical Literature, San Diego, 17-21 November

- 2007, 'Biblical spirituality, peace and a culture of violence', inaugural lecture, University of the Free State, 12 September.

- 2007, 'The spiritual reading of the Bible', workshop on Biblical Spirituality, Bloemfontein, 15-16 March, and Pietermaritzburg, 27-28 August.

- 2007, 'Life after death and eternal life according to the New Testament', Stellenbosch Central Study and Discussion Group, 23 October.

- 2008, 'Openbaring 18 as toetsteen vir nadenke oor geweld', paper read at a conference of the Dutch, Afrikaans and Flemish New Testament project (NAVNUT) on The New Testament and Violence, Stellenbosch, January.

- 2008, 'Love in Philemon', paper read at a conference on Perspectives on Philemon at the University of the Free State, Bloemfontein, September 2008.

- 2008, 'Moral language in Philemon', paper read at a conference (Humbolt-Kolleg) on Moral Language in the New Testament at the University of Pretoria, September.

- 2009, 'A spiritual reading of the Bible in a time of war: The twentieth century diary of Renske van der Walt', paper read at a conference of the Spirituality Association of South Africa (Spirasa), Pretoria, 17 April.

- 2009, 'Mysticism and the New Testament', paper read at the annual meeting of the New Testament Society of South Africa, Stellenbosch, July.

- 2009, 'The reception of violence in Oecumenius' commentary on Revelation', paper read at a conference on Violence in the Reception of Revelation in Louvain, 09-11 September.

- 2009, 'Numerical symbolism in Oecumenius' commentary on Revelation', paper read at a Conference on Die Kommentierung der Apokalypse von den Anfängen bis in 12. Jahrhundert, Innsbruck, Leopold-Franzens-University, Innsbruck, 28 September to 01 October.

- 2009, 'Reflections on spirituality: A new vision for a new discipline', paper read at a conference on Biblical Spirituality at the University of Nijmegen, 16 October.

- 2009, 'Theoretical and hermeneutical perspectives on Biblical spirituality', paper read at the University of Gloucestershire, United Kingdom, 27 October.

- 2010, 'The resurrection as Christ's entry in glory', paper read at a conference of the University of Gloucester, Gloucester, 04-06 May.

- 2010, 'A mystical reading of the Bible in a time of war (2): The twentieth century diary of A.H. Luckhoff', paper read at the Annual Meeting of the Spirituality Association of South Africa (SPIRASA).

- 2011, 'The church and its power in Revelation 11', paper presented at an international Conference of the Dutch, Afrikaans and Flemish New Testament project (NAVNUT) on the Bible and power, Stellenbosch, January.

- 2011, 'Love in the Letter to the Romans', paper read at a Conference in honour of Andrie du Toit's 80th birthday, organized by the Department of New Testament at the University of Pretoria.

- 2011, 'A new approach to the Gospel of Luke', paper read at a colloquium of the Titus Brandsma Institute, Radboud University, Nijmegen.

- 2011, 'An introduction to spirituality', workshop on Spirituality at a Meeting of the World Alliance of Reformed Churches, Johannesburg, 28-30 October.

- 2012, 'Historical, literary and mystical perspectives in Spinoza's Interpretation of the Torah', paper read on invitation at the international meeting of the Society of Biblical Literature, Amsterdam.

- 2012, 'Community discernment in Acts', paper read at an international conference on Discernment in the Bible and Spirituality, Malta, May. 
- 2012, 'The first fruit of the Spirit: Pauline perspectives on love', paper read at an international symposium on the Bible and Spirituality, hosted by the Centre of the Bible and Spirituality in the School of Humanities at the University of Gloucestershire, May.

- 2012, 'Enslaved in love: Perspectives on the theme of love in Paul's Letter to the Galatians', paper read at a conference on the Letter to the Galatians, Faculty of Theology, University of the Free State, 13-14 March.

- 2013, 'Discernment in spirituality: An overview', paper read at the annual meeting of the Spirituality Association of South Africa, January.

- 2013, 'Mysticism in John's Gospel and Philo', paper read at the annual meeting of the New Testament Society of South Africa, September.

- 2013 , 'In awe of the mighty deeds of God: Holy fear in the early church from the perspective of Biblical spirituality', opening and keynote address at the conference on Wondrous Fear and Holy Awe at the University of Notre Dame, 29 June - 02 July. Responses given by John T. Fitzgerald and Gary Anderson of the University of Notre Dame.

- 2014, 'Apocalyptic fervour and the socially disadvantaged', paper read at the conference on Perspectives on the Socially Disadvantaged in Early Christianity, held at the University of the Free State, Bloemfontein.

- 2014, 'Holiness in Mark's Gospel', paper read at the Annual Meeting of the Spirituality Association of South Africa, held at the University of South Africa, Pretoria, 11 August.

- 2014, 'Union with God in Philo and John's Gospel', paper read at the Annual Meeting of the New Testament Society of South Africa, University of the Free State, Bloemfontein, 22-25 April.

- 2014, 'Spiritual hermeneutics and Biblical spirituality as a new approach in New Testament Studies?', paper read at the international meeting of the Society of Biblical Literature in Vienna, 10 July.

- 2014, 'Perspectives on holiness', paper read at an International Meeting on Spirituality, Radboud University, Titus Brandsma Institute, Nijmegen, 27 May.

- 2014, 'Protecting the state against the church: The reception of John's Revelation in the first Greek commentary on Revelation', paper read at the Annual Meeting of the Society of Biblical Literature, San Diego, 24 November.

- 2014, 'Smuggling the Law through the back door?: The Law and love in the ethics, ethos, and identity of the Galatian community', paper read at the Annual Meeting of the Society of Biblical Literature (Biblical Ethics group), San Diego, 23 November.

- 2014, 'The violence of nonviolence in the reception history of the Apocalypse of John', paper read at the Use, Influence, and Impact of the Bible, Ideological Criticism Group of the Annual Meeting of the American Academy of Religion, San Diego, 25 November.

- 2015, 'Peace as a neglected theme in New Testament studies', paper read at a Conference of the Dutch, Afrikaans and Flemish New Testament project (NAVNUT) at North West University, Potchefstroom, January.

- 2015, 'Love and the Law in the Letter to the Romans', paper read at the Biblical Ethics Group of the Annual Meeting of the Society of Biblical Literature in Atlanta.

- 2015, 'A mystical perspective on the Christophany in Revelation', paper read at the Mysticism, Esotericism and Gnosticism in Antiquity Group of the Annual Meeting of the Society of Biblical Literature, Atlanta.

- 2015, 'What are the hallmarks of the spiritual interpretation of Scripture?', paper read at the Christian theology and the Bible Group of the Annual Meeting of the Society of Biblical Literature, Atlanta.

\section{List of publications Theses}

- 'Die teken van Jona', Th.Drs. thesis. Supervisor: Prof Herman Ridderbos.
- 'Jesus between resurrection and second coming. An investigation of the meaning of the exaltation in the speeches of Acts', (Original title: 'Jesus tussen opstanding en wederkoms. 'n Ondersoek na die betekenis van die verhoging volgens die toesprake in Handelinge') D.Th thesis, University of Stellenbosch.

\section{Research articles in scientific journals}

- 1978, 'Luke, Evangelist of salvation history', (Original title: 'Lukas as heilshistoriese evangelis', Nedertuise Gereformeerde Teologiese Tydskrif 19, 249-259.

- 1978, 'The Messiah and messiahs in Jewish apocalyptic', Neotestamentica 12, 75-110.

- 1981, 'Understanding the way of God: Form, function and message of the historical review in 4 Ezra 4-27', Society of Biblical Literature Seminar Papers 20, 357-375.

- 1982, 'Renaissance van die sosiologiese teksanalise', Theologia Evangelica 15, 19-32.

- 1982, 'Die diens van die gelowige in die Lukasgeskrifte', Scriptura 6, 13-27.

- 1982 , 'Configuration and plot in Matthew 19-22', Neotestamentica 16, 56-73.

- 1982 , 'The Ezra legend in 4 Ezra 14:1-48', circulated paper read at the annual meeting of the Society of Biblical Literature', New York, December.

- 1983, 'Die relevansie van ' $n$ linguistiese benadering tot die analise van klassieke tekste', Spil Plus 8, 52-61.

- 1983, “Judaisme" in die tydperk van die tweede tempel: 'n Herbesinning', Tydskrif vir Geesteswetenskappe 23, 30-37.

- $\quad 1983$, 'Revealing the secrets: Wisdom and the world in the Similitudes of Enoch', Neotestamentica 17, 50-68.

- 1982-1983, 'Solving the riddle?: Recent trends in apocalyptic research', Old Testament Essays, OTWSA, The exilic period, Aspects of apocalypticism 25-26, 39-58.

- 1984, 'The interpretation of a text in the light of its socio-cultural setting', Neotestamentica 18, 66-79.

- 1988, 'The Lord was crucified in Sodom and Egypt: Symbols in the Apocalypse of John', Neotestamentica 22, 125-138.

- 1989, 'New Testament scholarship in South Africa', Neotestamentica 23, 119-124.

- 1990, 'The medium is the message: Luke and the language of the New Testament against a Graeco-Roman background', Neotestamentica 24, 247-56.

- 1991, 'The end of hermeneutics?: On New Testament studies and postmodernism', Neotestamentica 25, 145-56.

- 1991, 'Dievernietiging van die bose: Voorbeelde van apokaliptiese denke in die moderne Afrikaanse digkuns', Tydskrif vir Geesteswetenskappe 31(3), 217-231.

- 1992, 'Helde in eie huis, Oor die etiek van 1 Timoteus', Scriptura 9, 223-240.

- $\quad 1993$, 'The Bible and the struggle (for power)', Scriptura 45, 1-28.

- 1993, 'Offering new life to a broken world: The Holy Spirit in Acts', Acta Academica 25, 50-66.

- 1996, 'The vice of conceit in 1 Timothy: A study in the ethics of the New Testament within its Graeco-Roman context', Acta Patristica et Byzantina 7, 37-67.

- 1997, 'Oracles and prophecies in the Graeco-Roman world and the Apocalypse of John', Acta Patristicaet Byzantina 8, 79-96.

- 1998 (co-author Germiquet, E.), 'Paul and paganism in Acts 17: Superstition in early Christianity and Graeco-Roman society', Acta Patristica et Byzantina 9, 35-51.

- 1998 (co-author Germiquet, E.), 'Religio and superstition in early Christianity and Graeco-Roman society: Christian perspectives on paganism', Acta Patristica et Byzantina 9, 52-69. 
- $\quad 1999$, 'The polemical task of feminist spiritualities', Scriptura 70, 195209.

- 1999, 'The rise and nature of feminist spirituality', HTS Teologiese Studies/Theological Studies 55(4), 1-25. http://dx.doi.org/10.4102/ hts.v55i4.1639

- 1999, 'The struggle for the soul of a discipline', Theologia Viatorum 25, 69-87.

- 1999, 'Obscure symbols in the Book of Revelation in the light of GraecoRoman pagan oracles and prophecies', Acta Patristica et Byzantina 10, 66-88.

- 1999, 'Interpreting the New Testament in the light of pagan criticisms of oracles and prophecies in Graeco-Roman Times', Neotestamentica 33, 35-57.

- $\quad$ 1999, 'The Psalms and spirituality', Old Testament Essays 12, 416-439.

- 2000, 'Prime evil and its many faces in the Book of Revelation', Neotestamentica 34, 57-86.

- 2000, 'A Pauline letter and a pagan prophet: Christian criticism of pagan prophecies', Acta Patristica et Byzantina 11, 74-92.

- 2002, 'Persecution in the Book of Revelation', Acta Theologica 22, 47-70.

- 2002, 'The composition of Revelation 17 and its place in the book as a whole', Acta Patristica et Byzantina 13, 97-119.

- 2002, 'Rome in the historical interpretation of Revelation', Acta Patristica et Byzantina 13, 120-142.

- 2002, 'Geskiedenis, geloof en die Evangelies: Perspektiewe op die verhouding tussen geskiedenis en teologie in die Bybelwetenskappe', Scriptura 80, 161-172.

- 2002, 'Renaissance and religion: The Bible in a time of radical change', Acta Theologica 22, 19-46.

- $\quad 2003$, 'Faith, hope and love: A missionary perspective on three seminal motifs in 1 Thessalonians 1:3', Acta Theologica 23(1), 36-53.

- 2003, 'History and religious experience in biblical research', HTS Teologiese Studies/Theological Studies 59, 693-714. http://dx.doi. org/10.4102/hts.v59i3.669

- 2003, 'Religieuse ervaring as hermeneutiese beginsel in die interpretasie van Bybeltekste in die lig van die boek Openbaring', Nederduitse Gereformeerde Teologiese Tydskrif 44, 276-286.

- 2003, 'Proclaiming the Gospel in Macedonia, Achaia and in every place: Missions and 1 Thessalonians 1:6-8', Acta Theologica 23(2), 43-57.

- 2004 , 'The role of composition in the interpretation of the Rider on the white horse and the seven seals in Revelation', HTS Teologiese Studies/ Theological Studies 60(1/2), 125-153. http://dx.doi.org/10.4102/hts. v60i1/2.526

- 2004, 'The composition of Revelation 14:1-15:8: Pastiche or perfect pattern?', Neotestamentica 38(2), 209-249.

- 2004, 'Paul as a letter writer: A new publication on Pauline letters in their literary setting', Scriptura 85, 136-147

- 2004, 'Armoede en gemeenskap in die Lukas-geskrifte: Aspekte van Lukaanse Spiritualiteit', Nederduitse Gereformeerde Teologiese Tydskrif 45(2), 244-255.

- 2004, 'The sixth seal in Revelation 6:12-17', Acta Theologica Supplementum 6, 1-30.

- 2004, 'The septets of seals and of angels in Revelation: A missing link?', Acta Patristica et Byzantina 15, 119-143.

- 2005, 'Turbulent times and golden years: The first twenty five years of The New Testament Society of South Africa (1965-1990)', Neotestamentica 39, 75-110.

- 2005, 'Methodology and hermeneutics in a challenging socio-political context: The first twenty five years of The New Testament Society of South Africa (1965-1990)', Neotestamentica 39, 229-255.

- 2005, 'The septet of bowls in Revelation 15:1-16: 21 in the light of its composition', Acta Patristica et Byzantina 16, 196-222.

- 2006, 'The heavenly joy of the faithful in Revelation', Acta Patristica et Byzantina 17, 206-226.
- 2006, 'Perverse joy in the book of Revelation: A perspective on religious experience', Acta Patristica et Byzantina 17, 227-242.

- 2006, 'A new society and its first publication, Acta Theologica Supplementum 8, i-v.

- 2006, 'Spirituality, theology and the critical mind', Acta Theologica Supplementum 8, 99-124.

- 2006, 'Perspectives on canon history and canonical criticism in the light of biblical spirituality', Scriptura 9(1), 117-126.

- 2006, 'Spirituality and New Testament studies: A new publication on the art of Christian living, with a special focus on homosexuality', Scriptura 9(1), 127-137.

- 2007 , 'Rethinking the contribution of Spinoza to theology and Biblical Studies', Studia Historiae Ecclesiasticae 33, 251-271.

- 2007, 'History, mysticism and ethics in Oecumenius: A hermeneutical perspective on the earliest extant Greek commentary on Revelation', Studia Historiae Ecclesiasticae 33, 315-336.

- 2007, 'Ignatius of Antioch in his pagan context', Studia Historiae Ecclesiasticae 33, 399-411.

- 2007, 'Divine and human love in the Revelation of John', Acta Patristica et Byzantina 18, 43-59.

- 2007, 'Herman Gunkel as innovator', Old Testament Essays 20, 333351.

- 2007, 'The eschatological celebration of salvation and prophetic announcement of judgement: The message of Revelation 8:1-6 in the light of its composition', Neotestamentica 41(1), 67-96.

- 2008, 'The eschatology of 1 Thessalonians in the light of its Spirituality', Acta Theologica 28, 1-32.

- 2008, 'Freedom to understand and serve: The contribution of Spinoza to Biblical Research', Studia Historiae Ecclesiasticae 34, 23-53.

- 2008, 'Aanbidding van God in die lig van Bybelse Spiritualiteit', Nederduitse Gereformeerde Teologiese Tydskrif 48, 124-139.

- 2008, 'Towards a spirituality of peace', Acta Theologica Supplementum 11, 20-58.

- 2008, 'Die ontmaskering van die bose: Eksegetiese perspektiewe op geweld in Openbaring 18', HTS Teologiese Studies 64, 1855-1893. http://dx.doi.org/10.4102/hts.v64i4.90

- 2008, 'Hermeneutiese perspektiewe op geweld in die Nuwe Testament', HTS Teologiese Studies/Theological Studies 64, 1923-1951. http:// dx.doi.org/10.4102/hts.v64i4.89

- 2008, "n Proloog tot hierdie bundel: 'n Unieke groep en perspektief op die Bybel en die Nuwe-Testamentiese Wetenskap', HTS Teologiese Studies/Theological Studies 64, 1579-1582. http://dx.doi.org/10.4102/ hts.v64i4.91

- 2008, 'Peace in Luke-Acts: A perspective on biblical spirituality', Acta Patristica et Byzantina 19, 110-134.

- 2009, 'Peace in the Pauline letters: A perspective on biblical spirituality', Neotestamentica 43, 1-26.

- 2009, 'The glory of the Son of man in Revelation 1-3: Reflections on mysticism in the New Testament', Acta Theologica 29, 17-39.

- 2009, 'Tranquility in the face of death: Calvinist spirituality in a time of war', Studia Historiae Ecclesiasticae 35, 119-139.

- 2010, 'The powerful transformation of the young man in Mark 14:5152 and 16:5', HTS Teologiese Studies/Theological Studies 66(1), 7 pages. http://dx.doi.org/10.4102/hts.v66i1.893

- 2011, 'The future existence of the believers according to 2 Thessalonians', HTS Teologiese Studies/Theological Studies 67(1), 10 pages. http://dx.doi.org/10.4102/hts.v67i1.912

- 2011, 'Reformed spirituality in action: The diary of A.D. Luckhoff as praxis', HTS Teologiese Studies/Theological Studies 67(3), 10 pages. http://dx.doi.org/10.4102/hts.v67i3.1109

- 2011, 'A spirituality of mercy in a time of war', Religion and Theology 18, 147-172.

- 2011, 'The resurrection as Christ's entry into his glory (Lk.24:6)', Acta Theologica 18, 101-131. 
- 2012, 'Die kerk en sy mag in Openbaring 11', HTS Teologiese Studies/ Theological Studies 68(1), 10 pages. http://dx.doi.org/10.4102/hts. v68i1.1176

- 2012, 'Oor nuwe aandag vir Joods-Christelike interpretasies van die paradys-motief: Die terugkeer van die paradys en skepping', Nederduitse Gereformeerde Teologiese Tydskrif 53, 33-47.

- 2012, 'Nelson Mandela als bron van inspiratie', Speling 64(4), 15-20.

- 2013, 'Communal discernment in the early church', Acta Theologica Supplementum 17, 132-155.

- 2013, 'Entering the corridors of power: State and church in the reception history of Revelation', Acta Theologica 33, 37-56.

- 2013, 'Fear as dread of God who kills and abuses?: About a darker side of a key, but forgotten biblical motif', HTS Teologiese Studies/ Theological Studies 69(1), Art. \#2018, 9 pages. http://dx.doi. org/10.4102/ hts.v69i1.2018

- 2014, 'Union with the transcendent God in Philo and John's Gospel', HTS Teologiese Studies/Theological Studies 70(1), Art. \#2749, 8 pages. http://dx.doi.org/10.4102/hts.v70i1.2749

- 2014, 'Transformation in love in Paul's Letter to the Galatians', Acta Theologica 19, 143-163.

- 2014 (co-authors J. Buitendag, \& A.G. van Aarde), 'The forgotten struggle of Albert Geyser against racism and apartheid', HTS Teologiese Studies/Theological Studies 70(1), 10 pages. http://dx.doi.org/10.4102/ hts.v70i1.2820

- 2015, 'The violence of nonviolence in the Revelation of John', Open Theology 1, 189-203.

- 2015, 'Vrede as 'n onontginde navorsingstema in die NuweTestamentiese wetenskap', HTS Teologiese Studies/Theological Studies 71(1), Art. 3001, xx pages. http://dx.doi.org/10.4102/hts.v71i1.3001

- 2015, 'Geweld en geweldloosheid in Openbaring', (Submitted for publication).

\section{Research chapters in books}

- 1986, 'Jesus and the divine man-tradition: Miracles in the world and time of the Bible', in P.G.R. de Villiers (ed.), Healing in the name of God, C.B. Powell Bible Centre, Pretoria.

- $\quad$ 1987, 'The gospel and the poor: Let us read Luke 4', in P.G.R. de Villiers (ed.), Liberation theology and the Bible, pp. 45-75, UNISA, Pretoria.

- 1987, 'Die apostelkonvent (Handelinge 15)' [The apostolic meeting (Acts 15)], in C. Breytenbach (ed.), Eenheid en konflik [Unity and conflict], N.G. Kerkboekhandel, Pretoria.

- 1988, 'Bybel, kerk en konteks' [Bible, church and context], in C. Breytenbach (ed.), Church in context, N.G. Kerkboekhandel, Pretoria.

- 1988, 'Die eenheid van die kerk: Handelinge 15' [The unity of the church: Acts 15], in P.G.R. de Villiers (ed.), Hoe lees ' $n$ mens die Bybel? [How do you read the Bible?], UNISA, Pretoria.

- 1988, 'Introduction: Revelation 9-11', in J.E. Botha, J. Engelbrecht \& P.G.R. de Villiers (eds.), Reading Revelation, Van Schaik, Pretoria.

- 1997, Articles in A.B. du Toit (red.), Handleiding by die Nuwe Testament: Die leefwêreld van die Nuwe Testament, Band II, bl. 441-469, Orion, Midrand.

- 2006, 'Wilhelm Bousset's commentary on Revelation and hermeneutical perspectives on the Revelation of John', in C. Breytenbach, J.C. Thom \& J. Punt (eds.), The New Testament interpreted, pp. 365-389, Brill, Leiden. (NTS 124).

- 2005, 'Safe in the family of God: Soteriological perspectives on 1 Thessalonians', in J.G. van der Watt (ed.), Salvation in the New Testament: Perspectives on soteriology, pp. 305-331, Brill, Leiden. (Supp NT 121).

- 2006, 'A lifeworthy of God: Identity and ethics in the Thessalonian correspondence', in J.G. van der Watt (ed.), assisted by F.S. Malan, Identity, ethics and ethos in the New Testament, pp. 335-356, Walter de Gruyter, Berlin.
- 2006, 'Heroes at home: Identity, ethos and ethics in 1 Timothy within the context of the Pastoral Epistles', in J.G. van der Watt (ed.), assisted by F.S. Malan, Identity, ethics and ethos in the New Testament, pp. 357-386, Walter de Gruyter, Berlin.

- 2008, 'Love in the Revelation of John', in H. Blommestijn (ed.), Seeing the seeker: Explorations in the discipline of spirituality, pp. 155-168, Peeters, Leuven. (Studies in Spirituality 19).

- 2010, 'Love in the Letter to Philemon', in D.F. Tolmie (ed.), Philemon in perspective: Interpreting a Pauline letter, pp. 181-203, Walter de Gruyter, Berlin.

- 2010, 'Moral language in Philemon', in R. Zimmermann \& J.G. van der Watt (eds.), Moral language in the New Testament, pp. 180-198, Mohr Siebeck, Tübingen.

- 2011, 'In the presence of God: The eschatology of 1 Thessalonians', in J.G. van der Watt (ed.), Eschatology of the New Testament and some related documents, pp. 302-332, Mohr Siebeck, Tübingen.

- 2011, 'The glorious presence of God: The eschatology of 2 Thessalonians', in J.G. van der Watt (ed.), Eschatology of the New Testament and some related documents, pp. 180-198, Mohr Siebeck, Tübingen.

- 2011, 'Coping with violent Scripture in a time of peace and prosperity: The interpretation of Revelation in the Greek Commentary of Oecumenius', in J. Verheyden, T. Nicklas \& A. Merkt (eds.), Ancient Christian interpretations of 'violent texts' in the Apocalypse, pp. 180198, Vandenhoeck \&Ruprecht, Göttingen.

- 2012, 'Preface', in P.G.R. de Villiers \& J.W. van Henten (eds.), Coping with violence in the New Testament, $\mathrm{pp}$. ix-x, Brill, Leiden.

- 2012, 'Unmasking and challenging evil: Exegetical perspectives on violence in Revelation 18', in P.G.R. de Villiers \& J.W. van Henten (eds.), Coping with violence in the New Testament, pp. 201-226, Brill, Leiden.

- 2012, 'Hermeneutical perspectives on violence in the New Testament', in P.G.R. de Villiers \& J.W. Van Henten, (eds.), Coping with violence in the New Testament, pp. 247-273, Brill, Leiden.

- 2013, 'Love in the Letter to the Galatians', in A.T. Lincoln, J.G. McConville \& L.K. Pietersen (eds.), The Bible and spirituality: Exploratory essays in reading Scripture spiritually, pp. 194-211, Cascade Books, Eugene, OR.

- 2014, 'Numerical symbolism in Oecumenius's commentary on Revelation', in K. Huber, R. Klotz \& C. Winterer (eds.), Tot Sacramenta quot verba: Zur kommentierung der Apokalypse des Johannes von den Anfängen bis ins 12. Jahrhundert, pp. 135-152, Aschendorf Verlag, Münster.

\section{Articles in dictionaries}

- Oxford Encyclopedia of the Bible and Ethics, Oxford University Press, Oxford.

- Violence

- Encyclopedia of the Bible and its reception, EBR; Walter De Gruyter, Berlin.

- Adoration

- Angels and angelic beings

- Astronomy

- Auditions

- Dragon

- Four Horsemen of the Apocalypse New Testament

\section{Edited books}

- 1986, Disinvestment and human suffering, C.U.M., Roodepoort.

- 1986, Essays on religious literature for children, UNISA, Pretoria.

- 1986, Standing by God in his hour of grieving, co-editor J.W. de Gruchy, UNISA, Pretoria.

- 1986, Healing in the name of God, UNISA, Pretoria.

- 1987, The realism of the text: A perspective on biblical authority, coeditor J.W. van Huyssteen, UNISA, Pretoria. 
- 1987, Like a roaring lion... Essays on the Bible, the church and demonic powers, UNISA, Pretoria.

- 1987, Liberation theology and the Bible, UNISA, Pretoria.

- $\quad 1988$, Hoe lees ' $n$ mens die Bybel?, UNISA, Pretoria.

- 1988, Reading Revelation, with E. Botha \& J. Engelbrecht, Van Schaik, Pretoria.

- 2006, The Spirit that moves: Orientation and issues in spirituality, Acta Theologica Supplementum.

- 2008, The Spirit that empowers: Perspectives on spirituality, Acta Theologica Supplementum.

- 2011, The Spirit that inspires: Perspectives on Biblical spirituality, Acta Theologica Supplementum.

- 2013, The Spirit that guides: Discernment in the Bible and spirituality, Acta Theologica Supplementum.

- 2013, Coping with violence in the New Testament, with J.W. Van Henten, Brill, Leiden.

\section{Translated books}

- 2000, Drie minute stilte op die lewenspad: 'n Jaar se gedagtes oor wysheid en geloof, Lux Verbi, Wellington.

- 2003, 1, 2 en 3 Johannes, Lux Verbi, Wellington.

- 2005 , ' $n$ Seisoen vir heel word, with a postcript, Lux Verbi, Wellington.

- 2005, Lion handboek tot die Bybel (Nuwe Testament), Lux Verbi, Wellington.

- 2007, Henri Nouwen: Die terugkeer van die verlore seun. 'n Ware verhaal oor tuiskoms, with a postcript, Lux Verbi, Wellington.

- 2007, D. \& J. Stoop, Die volledige ouerskapboek, with a postcript, Lux Verbi, Wellington

- 2007, D. \& J. Stoop, Die volledige huweliksboek, with a postcript, Lux Verbi, Wellington.

\section{Books}

- 1987, Leviatan aan 'n lintjie: Woord en wêreld van die sieners, Serva, Pretoria.

- 1999, Saam in God se span, Lux Verbi, Kaapstad.

- 1999, Kom gou, Here, Lux Verbi, Kaapstad.

- 2001, Jabes roep tot God, Lux Verbi, Wellington.

\section{University textbooks}

- 2000, Young churches in old cities: The contextual mission theology of selected Pauline Letters, 156 pages, Module (F6) on the Pauline Letters for the Southern Theological Education and Training Scheme, Salisbury, an associated institution of the University of Surrey, Salisbury, Great Britain. (Published by STETS).

- 2005, Revised Edition: Young churches in old cities: The contextual mission theology of selected Pauline Letters, 156 pages, Module (F6) on the Pauline Letters for the Southern Theological Education and Training Scheme, Salisbury, an associated institution of the University of Surrey, Salisbury, Great Britain. (Published by STETS).

\section{General articles}

- 1983, 'Pinkstersondag: Hand.2:1-13', in C.W. Burger \& D.J. Smit (reds.), Riglyne vir Paas- Hemelvaartsprediking, N.G. Kerk-Uitgewers, Kaapstad. (Woord teen die Lig 3).

- 1990, 'Acts10, Pentecost', Journal of Theology in Southern Africa.

- $\quad$ 1997, Articles in Studiebybel vir tieners, J.L. van Schaik, Pretoria.

- $\quad 2002$, '1 Tessalonisense: God se liefdesruimte in wankelrige tye', in C.W. Burger \& I. Nell (reds.), Draers van die waarheid, Buvton, Stellenbosch.

- 1999, 'Die tussentoestand', in H. Stander (red.), Die eindtyd, Carpe Diem, Vanderbijlpark.
- 2002, Contributions to Die groot gebedeboek, Lux Verbi, Wellington.

- 2002, Leefstyl-Bybel vir Vroue, Lux Verbi, Wellington, (Editor New Testament).

- 2007, Contributions to Gebedeboek vir die lewe, Lux Verbi, Wellington.

- 2008, Articles in Christelike Kernensiklopedie, Lux Verbi, Wellington.

- 2014, "n Afrikaanse kerkman wat apartheidstrukture laat steier het, word weer onthou', Litnet 26/2/2014, http://www.litnet.co.za/rsquonafrikaanse-kerkman-wat-apartheidstrukture-laat-steier-het-wordweer-onthou/

- Various articles in newspapers and church journals.

\section{Book Reviews}

- 2003, Jonathan Knight, Revelation. Reviewed in Review of Biblical Literature (3/2003), http://www.bookreviews.org/pdf/446_3161.pdf

- 2003, Walter Wangerin, Die Boek van God: Die verhaal van die Bybel: 'n Roman. Reviewed in Die Burger (23/6/2003). http://152.111.1.87/ argief/berigte/dieburger/2003/06/09/DB/9LDNk/04.html

- 2004, Thomas a Kempis, Die Navolging van Christus. Reviewed in Die Burger (27/9/2004). http://152.111.1.87/argief/berigte/ dieburger/2004/09/27/DB/11LDN/02.html

- 2004, T.N. Wright, The resurrection of the Son of God. Reviewed in Review of Biblical Literature (12/2004). http://www.bookreviews.org/ pdf/3181_3552.pdf

- 2005, Barbara Rossing, The rapture exposed. Reviewed in Review of Biblical Literature (2005). http://www.bookreviews.org/ pdf/4595_4706.pdf

- 2005, D. Rhoads (ed.), From every people and nation. Reviewed in Review of Biblical Literature (2005). http://www.bookreviews.org/ pdf/4726_4868.pdf

- 2007, Antonius Siew, The war between the two beasts and the two witnessess: A Chiastic reading of Revelation 11.1-14.5. Reviewed in Review of Biblical Literature (2/2007). http://www.bookreviews.org/ bookdetail.asp?Titleld $=5115$

- 2015, N.T. Wright, The resurrection of the Son of God; Barbara R. Rossing, The rapture exposed: The message of hope in the Book of Revelation; Piet Muller, Die lewe na die dood: Sal ons nog droom as ons dood is? Reviewed in Die Burger (14/3/2015). http://152.111.1.87/ argief/berigte/dieburger/2005/03/14/DB/9LDN/01.html

- 2005, Alan de Botton, Status anxiety. Reviewed in Beeld (20/6/2005) http://152.111.1.88/argief/berigte/beeld/2005/06/20/B1/13A/02. html

- 2006, Luke Timothy Johnson, The living gospel. Reviewed in Scriptura 91 (2006), 127-137.

- 2007, Catherine A. Cory, The Book of Revelation. Reviewed in Review of Biblical Literature 3 (2007). http://www.bookreviews.org/bookdetail. asp?Titleld=5262.

- 2007, Gunkel, Hermann, Creation and chaos in the primeval era and the eschaton: A Religio-historical study of Genesis 1 and Revelation 12, transl. K.W. Whitney Jr. Reviewed in Review of Biblical Literature (11/2007). http://www.bookreviews.org/bookdetail.asp?Titleld=5560

- 2007, John N. Suggit, transl. Oecumenius: Commentary on the Apocalypse, (The Fathers of the Church 112). Reviewed in Review of Biblical Literature (12/2007). http://www.bookreviews.org/ pdf/5441_5735.pdf

- 2008, Ben Witherington, Revelation. Reviewed in Neotestamentica 42 (2008).

- 2008 , J.S. Kruger, Orientation to mysticism. Reviewed in Acta Theologica Supplementum 11 (2008), 261-264.

- 2013, V. Gilbert Beers, Reis deur die Bybel. Reviewed in Litnet (9/5/2013). http://www.litnet.co.za/reis-deur-die-bybel-n-resensie/

- 2013, Angus Buchan, Die mighty men verhaal. Reviewed in Litnet (9/5/2013). http://www.litnet.co.za/angus-buchan-en-manlikheidpieter-de-villiers-reageer/ 
- 2014, Roelf Schoeman, Weermagstories. Lux Verbi.Reviewed in Litnet (18/9/2014). http://www.litnet.co.za/litnet-akademies-resensie-essayweermagstories-deur-roelf-schoeman/.

- 2014, Chris van der Merwe, Die wonder van die goddelike liefde. Reviewed in Litnet (2/4/2014). http://www.litnet.co.za/die-wondervan-die-goddelike-liefde-deur-chris-van-der-merwe/

- 2014,InterliniêreBybel:Grieks-Afrikaans. ReviewedinLitnet(10/7/2014). http://www.litnet.co.za/poolshoogte-afrikaans-se-grootstetopverkoper/

- 2015, Jerome F.D. Creach, Violence in Scripture. Reviewed in Review of Biblical Literature (4/2015). http://www.bookreviews.org/bookdetail.
asp?Titleld $=9513$ \&CodePage $=5560,4726,5604,5441,446,6243,5262$ 4595,3181,5115,6387,9513.

- 2015, Markus Bockmuehl \& Guy G. Stroumsa (eds.), Paradise in antiquity: Jewish and Christian Views. Reviewed in Review of Biblical Literature (5/2015). http://www.bookreviews.org/bookdetail.asp?Titleld=7864.

\section{Bible translations}

- Translated Acts in the New Afrikaans Translation of the Bible (Acts), Bible Society of South Africa.

- Translated Acts in the Interlinear Bible (C.U.M., Vereeniging). 